\title{
BENEFICIAL OWNERSHIP DAN KEWAJIBAN PELAPORAN ATAS TRANSAKSI KEUANGAN MENCURIGAKAN
}

\author{
Armansyah \\ Dosen Hukum Pidana Profesi Prodi Kenotariatan Magister Universitas Pancasila \\ Triastuti \\ Alumni Prodi Kenotariatan Magister Universitas Pancasila \\ Senior Staff Priority Banking Officer BTN Kancab Jakarta Cawang
}

\begin{abstract}
ABSTRAK
Dimasukannya Notaris sebagai pelapor atas transaksi mencurigakan, Notaris berperan sebagai gatekeeper dalam tindak pidana pencucian uang, namun terkendala confidentiality of client yaitu menjaga kerahasiaan segala sesuatu mengenai aktanya. Upaya mengatasi kendala pencegahan tindak pidana pencucian uang terkait confidentiality of client sebagai kewajiban pelaporan bagi notaris, antara lain: menerapkan prinsip mengenali Pengguna Jasa Notaris sedangkan menurut Undang-Undang Jabatan Notaris (UUJN) mewajibkan notaris untuk merahasiakan akta yang dibuatnya. Kewajiban memperoleh informasi pemilik manfaat juga perlu dilakukan oleh notaris apabila berkaiatan dengan perikatan lain, bahkan notaris wajib melakukan identifikasi lebih mendalam apabila pemilik manfaat memiliki tingkat risiko terjadinya tindak pidana pencucian uang atau pendanaan terorisme yang tergolong tinggi.
\end{abstract}

Kata kunci : Kerahasiaan Klien, Pemilik Manfaat, Pencucian Uang

\begin{abstract}
While notary is able to report a suspicious transaction, notary indirectly performs gatekeeping in money laundering law enforcement. However, this function is constrained by the confidentiality of client principle disallowing the notary to disclose the non-public element in the certificate. To overcome this obstacle of money laundering prevention in regard with the issue, notaries should apply the principle in which the notary ought to recognize his/her clients. The obligation to obtain the clients' confidential information must be fulfilled by notaries. Moreover, the notary is obliged to make deeper identification is the owner of beneficial owner has a high risk of money laundering of terrorism financing.
\end{abstract}

Keywords : clients' confidentiality, Beneficial Ownership, Money Laundering 


\section{PENDAHULUAN}

Peraturan Mahkamah Agung (Perma) Nomor 13 Tahun 2016 tentang Tata Cara Penanganan Tindak Pidana Korporasi menjadi pedoman bagi penegak hukum dalam penanganan perkara pidana dengan pelaku korporasi dan atau pengurusnya.

Perma ini mengisi kekosongan hukum acara pidana dalam penanganan perkara pidana dengan pelaku korporasi atau pengurus. Atas dasar itu, Perma ini dapat mendorong efektifitas dan optimalisasi penanganan perkara pidana dengan pelaku korporasi dan atau pengurusnya.

Lantas dimanakah letak relasi antara notaris dengan pencucian uang dan kewajiban pelaporan apabila terindikasi transaksi keuangan mencurigakan, sedangkan disisi lain terdapat kewajiban merahasiakan klien oleh notaris ? Notaris merupakan salah satu profesi yang wajib menyampaikan laporan tranksaksi mencurigakan (TKM) kepada Pusat Pelaporan dan Analisis Transaksi Keuangan (PPATK) sebagaimana Peraturan Pemerintah (PP) No. 43 Tahun 2015 tentang Pihak Pelapor dalam Pencegahan dan Pemberantasan Tindak Pidana Pencucian Uang. Tindak lanjut atau peraturan pelaksanaan dari PP No. 43 Tahun 2015 tersebut, maka diterbitkanlah aturan pelaksanaannya yaitu Peraturan Menteri Hukum dan Hak Asasi Manusia Republik Indonesia No. 9 Tahun 2017. Dalam hal ini, transaksi keuangan yang menyimpang dari profil, karakteristik, atau kebiasaan pola transaksi dari Pengguna Jasa yang bersangkutan.

Untuk lebih mendalami tugas dan kewenangan notaris, maka akan dideskripsikan esensi dari Notaris baik sebagai profesi ataupun jabatan, mengingat berdasarkan instrument hukum yang disampaikan diawal notaris berkewajiban melaporkan TKM dan terkesan notaris menjadi bagian dari penegakan hukum anti pencucian uang. Pengertian notaris dalam system Civil Law yang diatur dalam Pasal 1 Ord, stbl. 1860 Nomor 3 tentang Jabatan Notaris di Indonesia mulai berlaku tanggal 1 Juli 1860 yang kemudian diterjemahkan oleh R. Soegondo disebutkan pengertian notaris adalah sebagai berikut :

Notaris adalah pejabat umum, khususnya (satu-satunya) yang berwenang untuk membuat akta-akta otentik tentang semua tindakan, perjanjianperjanjian, dan keputusan-keputusan yang diharuskan oleh perundangundangan umum untuk dikehendaki oleh yang berkepentingan bahwa hal itu dinyatakan dalam surat otentik, menjamin tanggalnya, menyimpan akta-akta 
dan mengeluarkan grosse, salinan-salinan (turunan-turunan) dan kutipankutipannya, semuanya itu apabila pembuatan akta-akta demikian itu atau dikhususkan itu atau dikhususkan kepada pejabat-pejabat atau orang-orang lain. ${ }^{1}$

Demi untuk kepentingan Notaris dan untuk melayani kepentingan masyarakat Indonesia, maka pemerintah berupaya pada tanggal 6 Oktober 2004 telah disahkan Peraturan Jabatan Notaris yang kita sebut dengan Undang-Undang Nomor 30 Tahun 2004 tentang Jabatan Notaris (UUJN). Berdasarkan sejarah, notaris adalah seorang pejabat Negara/pejabat umum yang dapat diangkat oleh Negara untuk melakukan tugas-tugas negara dalam pelayanan hukum kepada masyarakat demi tercapainya kepastian hukum sebagai pejabat pembuat akta otentik dalam hal keperdataan. Pengertian Notaris terdapat dalam ketentuan UU Jabatan Notaris Bab I Pasal angka 1 yaitu, Notaris adalah pejabat umum yang berwenang dan mewakili kekuasaan umum untuk membuat akta otentik dan kewenangan lainnya sebagaimana dimaksud dalam Undang-Undang ini, untuk kepentingan pembuktian atau sebagai alat bukti.

Notaris sebagai salah satu penegak hukum karena notaris membuat alat bukti tertulis yang mempunyai kekuatan pembuktian. Para ahli hukum berpendapat bahwa akta notaris dapat diterima dalam pengadilan sebagai bukti yang mutlak mengenai isinya, tetapi meskipun demikian dapat diadakan penyangkalan dengan bukti sebaliknya oleh saksi-saksi, yang dapat membuktikan bahwa apa yang diterangkan oleh notaris dalam aktanya adalah benar. ${ }^{2}$

G.H.S. Lumban Tobing memberikan pengertian notaris adalah pejabat umum yang satu-satunya berwenang untuk membuat akta otentik mengenai semua perbuatan, perjanjian dan penetapan yang diharuskan oleh suatu peraturan umum atau oleh yang berkepentingan dikehendaki untuk dinyatakan dalam suatu akta otentik, menjamin kepastian tanggalnya, menyimpan aktanya dan memberikan grosse, salinan dan kutipannya, semuanya sepanjang pembuatan akta itu tidak juga ditugaskan atau dikecualikan kepada pejabat atau orang lain. Notaris wajib untuk merahasiakan segala sesuatu yang dipercayakan kepadanya dan tidak boleh

\footnotetext{
${ }^{1}$ Tan Thong Kie, Studi Notariat, Serba-serbi Praktek Notaris, Buku I (Jakarta :PT Ichtiar Baru Van Hoeve, 2000), hlm. 158.

${ }^{2}$ Liliana Tedjosaputro, Malpraktek Notaris dan Hukum Pidana, (Semarang: CV. Agung, 1991), hlm. 4.
} 
menyerahkan salinan-salinan dari akta-akta kepada orang-orang yang tidak berkepentingan. ${ }^{3}$

Untuk menciptakan transparansi atas beneficial ownership terus dilakukan Pemerintah. Salah satu upaya tersebut adalah dengan menerbitkan Peraturan Menteri Hukum dan Hak Asasi Manusia Nomor 9 Tahun 2017 berkaitan dengan peran notaris terkait beneficial ownership. Permenhukam tersebut menjelaskan secara rinci definisi pemilik manfaat dan berbagai kewajiban yang dibebankan kepada notaris terhadap pemilik manfaat. Permenhukham yang berjudul "Penerapan Prinsip Mengenali Pengguna Jasa Bagi Notaris" ini pada prinsipnya bertujuan untuk mengatur agar para notaris harus mengenali secara mendalam pengguna jasanya.

Selain jasa profesional, termasuk tuntutan transparansi korporasi di Indonesia ditandai kewajiban pengungkapan sekaligus penerapan prinsip mengenali pemilik manfaat perusahaan dalam rangka pencegahan dan pemberantasan tindak pidana pencucian uang (TPPU) dan pendanaan terorisme. Termutakhir, payung hukum dari kebijakan ini adalah Peraturan Presiden (Perpres) Nomor 13 Tahun 2018 tentang Penerapan Prinsip Mengenali Pemilik Manfaat Dari Korporasi Dalam Rangka Pencegahan dan Pemberantasan Tindak Pidana Pencucian Uang dan Tindak Pidana Pendanaan Terorisme, berlaku sejak diundangkan pada 1 Maret 2018.

Dalam Perpres tersebut pemerintah beranggapan bahwa korporasi dapat dijadikan sarana bagi pelaku tindak pidana pemilik manfaat dari hasil TPPU dan pendanaan terorisme. Penerima manfaat dimaksud dalam beleid ini adalah individu yang dapat menunjuk atau memberhentikan direksi, dewan komisaris, pengurus, pembina, atau pengawas pada korporasi, serta memiliki kemampuan mengendalikan perusahaan. Prinsipnya, seluruh korporasi diwajibkan menyerahkan laporan mengenai pemilik manfaat korporasi, dan pelaporan bisa dilakukan oleh pendiri atau pengurus korporasi, atau pihak lain yang diberi kuasa oleh pendiri atau pengurus, dan tentunya dalam kaitan dengan topik ini adalah bahwa pelaporan dapat dilakukan oleh Notaris.

${ }^{3}$ G.H.S Lumban Tobing, Peraturan Jabatan Notaris (Notaris Reglement), (Jakarta: Erlangga, 1999), hlm. 31. 
Notaris sebagai pejabat umum, yang berarti kepadanya diberikan dan dilengkapi dengan kewenangan atau kekuasaan umum yang menyangkut publik (openbaar gezag). Pasal tersebut mengartikan agar suatu akta memiliki kekuatan bukti otentik, maka haruslah ada kewenangan dari pejabat umum yang dalam hal ini notaris, untuk membuat akta otentik yang bersumber dari Undang-Undang. ${ }^{4}$

Ketentuan Pasal 4 ayat (2) dan Pasal 16 ayat (1) huruf (f) Undang Undang Nomor 2 Tahun 2014 tentang Perubahan Atas Undang-Undang Nomor 30 Tahun 2004 tentang Jabatan Notaris (UUJN), ditegaskan bahwa notaris berkewajiban merahasiakan segala sesuatu mengenai akta yang dibuatnya dan segala keterangan yang diperoleh dalam pembuatan akta sesuai dengan sumpah/janji jabatan, kecuali Undang-Undang menentukan lain.

Di sisi lain, dalam konteks notaris dan penegakan hukum dipandang notaris bagian dari penegakan hukum tersebut. Penegakan hukum adalah proses fungsionalisasi norma-norma hukum secara nyata sebagai pedoman perilaku atau hubungan-hubungan hukum dalam berperikehidupan, sehingga dituntut kesadaran hukum untuk memperkuat penegakan hukum dalam sistem hukum nasional Indonesia. Faktor kesadaran manusia ini merupakan salah satu faktor yang paling berpengaruh terhadap penegakan hukum, termasuk dalam hal ini untuk penegakan hukum terhadap notaris. ${ }^{5}$

Dalam menjalankan jabatannya notaris senantiasa bersikap profesional dengan dilandasi kepribadian luhur melaksanakan tugasnya sesuai peraturan perundang-undangan sekaligus menjunjung tinggi kode etik profesi. Perilaku yang tidak profesional dapat menjadi celah penyalahgunaan tugas dan wewenang notaris, yang diatur oleh undang-undang dan sumber-sumber hukum lain yang menjadi landasan notaris bertugas. Hingga pada akhirnya sangat memungkinkan terjadinya tindak pidana yang dilakukan oleh notaris tersebut.

Dalam UUJN memang tidak ada ketentuan pidana bagi notaris, namun hal tersebut tidak berarti bahwa notaris memiliki imunitas terhadap hukum. Notaris yang tidak profesional ketika menjalankan tugasnya sebagai pejabat umum

\footnotetext{
hlm. 30 .

${ }^{4}$ Budi Untung, Hukum Koperasi dan Peran Notaris Indonesia, (Yogyakarta: Andi, 2005),

5 Liliana Tedjosaputro, Etika Profesi Notaris (Dalam Penegakan Hukum Pidana), (Yogayakarta: Bigraf Publishing, 1995), hlm. 69.
} 
berpotensi melakukan tindak pidana umum yang diatur dalam Kitab UndangUndang Hukum Pidana (untuk selanjutnya disebut KUHP), seperti pemalsuan dokumen atau surat (Pasal 263 dan Pasal 264 KUHP), Penggelapan (Pasal 372 dan Pasal 374 KUHP). Sedangkan, untuk tindak pidana khusus notaris dapat diperiksa terkait tindak pidana korupsi atau bahkan kerap kali jasa notaris digunakan untuk melakukan tindak pidana pencucian uang (TPPU) yang dapat merugikan keuangan/perekonomian negara.

Jabatan notaris sering pula disebut dengan jabatan kepercayaan. Kepercayaan Pemerintah sebagai instansi yang mengangkat dan memberhentikan notaris sekaligus pula kepercayaan masyarakat sebagai pengguna jasa notaris. Oleh karena itu, profesi notaris merupakan orang yang menjadi kepercayaan masyarakat, karena itu kedudukannya harus dijunjung tinggi.",6

Untuk melindungi unsur kepercayaan masyarakat kepada notaris, sebagaimana profesi lainnya notaris mempunyai kewajiban untuk merahasiakan informasi yang diperoleh kliennya. Kewajiban merahasiakan akta autentik yang dibuat oleh notaris adalah keseluruhan dari isi akta dan dokumen yang melekat di dalam akta tersebut. Dengan merahasiakan isi akta dan keterangan baik lisan maupun tertulis yang diperoleh guna pembuatan akta, menjadikan hal tersebut sebagai rahasia jabatan notaris. Dalam UUJN dinyatakan bahwa, negara mempunyai memberikan kewajiban kepada notaris untuk merahasiakan isi akta dan segala keterangan yang diperoleh guna pembuatan akta autentik tersebut. ${ }^{7}$

Disisi lain dengan terbitnya Peraturan Pemerintah Nomor 43 Tahun 2015 tentang Pihak Pelapor Dalam Pencegahan dan Pemberantasan Tindak Pidana Pencucian Uang (PP No. 43 Tahun 2015). Dalam ketentuan PP No. 43 Tahun 2015 ini, menjelaskan mengenai kewajiban notaris lainnya dalam membantu pencegahan dan pemberantasan TPPU. PP ini mewajibkan mereka yang biasa disebut gatekeeper profesional untuk melapor ke Pusat Pelaporan dan Analisis Transaksi Keuangan (PPATK).

\footnotetext{
${ }^{6}$ Raden Soegondo Notodisoerjo, Hukum Notariat di Indonesia suatu Penjelasan, cetakan kedua, (Jakarta: PT. Raja Grafindo Persada, 1993), hlm. 46.

${ }^{7}$ Indonesia, Undang-Undang Republik Indonesia tentang Perubahan Atas Undang-Undang Nomor 30 Tahun 2004 tentang Jabatan Notaris, UU No. 2 LN Tahun 2014 No. 3, TLN No. 5491 , Pasal 16 ayat (1) huruf f.
} 


\section{PEMBAHASAN}

\section{A. Dilema Rahasia Jabatan dan Kewajiban Pelaporan Indikasi TKM}

Penggunaan hak untuk merahasiakan sesuatu yang berkaitan dengan jabatan diatur juga dalam Pasal 170 ayat (1) KUHAP menyatakan bahwa, mereka yang karena pekerjaan, harkat, martabat, atau juga jabatannya diwajibkan untuk menyimpan rahasia, dapat diminta dibebaskan dari penggunaan hak untuk memberikan keterangan sebagai saksi, yaitu tentang hal yang dipercayakan kepadanya. Pasal 50 dan 51 ayat (1) KUHPidana menegaskan bahwa "Barang siapa melakukan perbuatan untuk melaksanakan ketentuan Undang-Undang dan melakukan perbuatan untuk melaksanakan perintah jabatan yang diberikan oleh penguasa yang berwenang, tidak dipidana"

Di antara faktor penyebab modus pencucian uang dengan menggunakan jasa notaris adalah karena tidak dikategorikannya notaris sebagai gate keeper sebagaimana dalam Pasal 17 ayat (1) UU PPTPPU sebagai pihak pelapor. Hal ini menyebabkan tidak ada kewajiban bagi notaris untuk memberikan laporan kepada PPATK mengenai transaksi keuangan mencurigakan (TKM) yang dilakukan oleh para pihak, sehingga pelaku pencucian uang memanfaatkan jasa notaris untuk menyembunyikan dan menyamarkan uang hasil kejahatan. Hal inilah yang menjadi latar belakang dikeluarkannya PP No. 43 Tahun 2015 yang menjadikan Notaris sebagai pihak pelapor TPPU.

Berdasarkan Peraturan Pemerintah ini terkait dengan salah satu prinsip notaris yang menjadi pedoman dalam menjalankan kewajibannya yaitu confidentiality of client atau prinsip menjaga kerahasiaan klien. Hal ini, termaksud dalam Pasal 16 ayat (1) huruf f UUJN yang menyatakan: Salah satu bentuk dari notaris sebagai jabatan kepercayaan, yaitu notaris mempunyai kewajiban untuk merahasiakan segala sesuatu mengenai akta yang dibuatnya dan segala keterangan yang diperoleh guna pembuatan akta sesuai dengan sumpah/janji jabatan, kecuali Undang-Undang menentukan lain.

Namun demikian, terdapat kendala dalam penerapan Pasal 6 ayat (1) PP No. 43 Tahun 2015 dalam hal pencegahan TPPU dan pelaksanaan prinsip mengenali pengguna jasa yang diatur dalam Permenkumham Nomor 9 Tahun 2017 tentang Penerapan Prinsip Mengenali Pengguna Jasa. Berkaitan dengan akta yang dibuat 
dihadapan notaris, notaris tidak lepas dari adanya suatu indikasi TKM terhadap pengguna jasa notaris seperti dapat saja para pihak yang merupakan pelaku TPPU yang memanfaatkan jasa notaris dengan membuat akta otentik atas suatu transaksi yang memperoleh dari hasil perbuatan tindak pidana (illegal). Kemungkinan perbuatan ini dilakukan pelaku agar transaksi pencucian uang tersebut terhindar dari jeratan hukum karena adanya kerahasian jabatan yang dimiliki notaris.

Pada umumnya pelaku tindak pidana selalu berusaha menyembunyikan atau menyamarkan asal usul harta kekayaan yang merupakan hasil dari tindak pidana dengan berbagai cara agar harta kekayaan hasil tindak pidananya susah ditelusuri oleh aparat penegak hukum.

Menurut Pasal 1 ayat (8) PP No. 43 Tahun 2015, TKM adalah:

a. Transaksi keuangan yang menyimpang dari profil, karakteristik, atau kebiasaan pola transaksi dari pengguna jasa yang bersangkutan;

b. Transaksi keuangan oleh pengguna jasa yang patut diduga dilakukan dengan tujuan untuk menghindari pelaporan transaksi yang bersangkutan yang wajib dilakukan oleh pihak pelapor sesuai dengan ketentuan undang-undang ini;

c. Transaksi keuangan yang dilakukan atau batal dilakukan dengan menggunakan harta kekayaan yang diduga berasal dari hasil tindak pidana; atau;

d. Transaksi keuangan yang diminta oleh PPATK untuk dilaporkan oleh pihak pelapor karena melibatkan harta kekayaan yang diduga berasal dari hasil tindak pidana.

Dengan adanya PP No. 43 Tahun 2015 dengan aturan pelaksanaannya Permenkumham Nomor 9 Tahun 2017, sebagaimana dalam Pasal 3 Peraturan Pemerintah ini ditegaskan bahwa notaris sebagai pihak pelapor atas dugaan TPPU atas akta yang dibuatnya. PP ini merupakan peraturan pelaksana ketentuan Pasal 17 ayat (2) UUPPTPU.

Konsep Notaris sebagai pihak pelapor atas TKM terkait TPPU harus dirumuskan secara jelas dalam peraturan perundang-undangan, hal ini sebagai konsekuensi atas ketentuan pengecualian kerahasiaan akta yang melekat pada notaris yang hanya bisa dibuka jika Undang-Undang menentukan secara tegas. Kewajiban notaris atas kerahasiaan akta yang dibuatnya tetapi disatu sisi sebagai Pelapor TKM berdasarkan UUJN dan UUPPTPU serta Permenkumham No. 9 Tahun 2017 menjadi dilematis. Terlebih apabila diketahui, apabila tidak dilaporkannya TKM dapat dikenakan ancaman Pasal 322 KUHP yang 
menyatakan bahwa "Barang siapa dengan sengaja membuka rahasia yang wajib disimpannya karena jabatan atau pencariannya, baik yang sekarang maupun yang dahulu, diancam dengan pidana penjara paling lama sembilan bulan atau pidana denda paling banyak sembilan ribu rupiah."

\section{B. Modus Operandi dan Mengenal Pengguna Jasa}

Modus operandi dari pencucian uang yang semakin canggih karena memanfaatkan profesional di bidang keuangan atau hukum dengan keahlian, pengetahuan, dan akses khusus kepada sistem keuangan global, yang mencoba memanfaatkan peluang melalui keahlian mereka untuk mengamankan hasil tindak pidana. Salah satu bentuk TKM yang menjadi modus pelaku TPPU adalah bisnis jual beli real estate dan perumahan. Seiring dengan semakin ketatnya lembagalembaga perbankan membuat para pelaku TPPU untuk mengalihkan modus pencucian uangnya ke jual beli real estate/ tanah dan/atau bangunan. Setidaknya ada dua faktor pendukung mengapa pelaku lebih banyak menggunakan modus pencucian uang dengan cara jual beli real estate yaitu, pertama real estate merupakan salah satu bentuk investasi yang sangat menjanjikan karena nilai ekonomisnya terus mengalami peningkatan. Faktor pendukung kedua mengapa pelaku TPPU menggunakan modus pencucian uang melalui penggunaan jasa Notaris karena kedua profesi ini dianggap tidak dikategorikan sebagai pihak pelapor dalam UU PPTPPU. Tidak seperti lembaga perbankan dan lembaga pembiayaan yang dikategorikan sebagai pihak pelapor yang wajib menyampaikan laporan apabila terdapat TKM.

Kedudukan sumpah/janji jabatan memiliki peranan penting bagi Notaris selaku pejabat umum yang diberi kewenangan untuk membuat akta otentik dan memiliki kewenangan lainnya sebagaimana ditentukan dalam UUJN. Notaris sebagai jabatan kepercayaan wajib untuk menyimpan rahasia mengenai akta yang dibuatnya dan keterangan/pernyataan para pihak yang diperoleh dalam pembuatan akta, kecuali undang-undang memerintahkannya untuk membuka rahasia dan memberikan keterangan/ pernyataan tersebut kepada pihak yang memintanya. ${ }^{8}$ Sehubungan dengan kewajiban merahasiakan isi akta dan segala keterangan lain yang berkaitan dengan akta notaris, maka kerahasiaan ini memberikan ruang

${ }^{8}$ Habib Adjie, Menjalin Pemikiran-Pendapat Tentang Kenotariatan (Kumpulan Tulisan), (Bandung: PT.Citra Aditya Bakti, 2013), hlm. 132. 
gerak yang leluasa/celah bagi pergerakan dana hasil tindak pidana melalui jasa yang diberikan oleh notaris yang kemudian dimanfaaatkan oleh para pelaku untuk melakukan kegiatan TPPU.

Guru Besar Fakultas Hukum Universitas Padjadjaran Bandung, Romli Atmasasmita, berpendapat PP No. 43 Tahun 2015, sulit untuk dijalankan di lapangan. Apalagi ada sanksi balik kepada notaris. Di satu sisi notaris diwajibkan melapor, tetapi di sisi lain tak ada insentif yang diberikan kepada notaris yang sudah melapor. ${ }^{9}$ Berdasarkan Pasal 23 ayat (1) Perka PPATK No. 11 Tahun 2016, membatasi jangka waktu pelaporan transaksi yang mencurigakan dari penghadap selama 3 (tiga) hari sejak sejak diketahui. Selain jangka waktu yang singkat, masih ada ancaman sanksi administratif yang bisa dikenakan oleh PPATK kepada notaris. Mulai dari teguran tertulis; pengumuman kepada publik mengenai tindakan atau sanksi; hingga denda administratif, namun tidak disebutkan besaran denda yang dapat dikenakan.

Kendala dalam penerapan prinsip mengenali Pengguna Jasa Notaris juga merupakan persoalan di kalangan profesi notaris. Dalam Permenkumham No. 9 Tahun 2017 mengenai TKM yang dilakukan oleh klien atau calon kliennya (dalam hal ini di sebut sebagai Pengguna Jasa), wajib di waspadai dan wajib pula dilaporkan oleh Notaris kepada PPATK. Jika dikaitkan dengan ketentuan Pasal 18 UU PPTPU disebutkan bahwa pihak pelapor wajib menerapkan prinsip mengenali Pengguna Jasa. Hal ini ditegaskan pula dalam Pasal 8 PP No. 43 Tahun 2015, yang menyebutkan bahwa pihak pelapor sebagaimana dimaksud dalam Pasal 3 wajib menyampaikan laporan TKM kepada PPATK untuk kepentingan atau untuk dan atas nama Pengguna Jasa.

Pada prinsipnya notaris harus mengenali kliennya atau dalam Permenkumham tersebut disebut sebagai Pengguna Jasa, dengan cara:

a. Identifikasi Pengguna Jasa;

\footnotetext{
9 "Kewajiban Notaris Melaporkan Transaksi Mencurigakan Dinilai Kurang Tepat, Begini Alasannya", terdapat disitus http://www.hukumonline.com/berita/baca/lt59817aaf33abc/kewajiban-notaris-melaporkantransaksi-mencurigakan-dinilai-kurang-tepat--begini-alasannya, diakses pada tanggal 29 Oktober 2017.
} 
Notaris melakukan identifikasi melalui pengumpulan informasi Pengguna Jasa Pengumpulan informasi mengenai Pengguna Jasa dilakukan terhadap orang perseorangan, Korporasi; dan perikatan lainnya (legal arrangements).

b. Verifikasi Pengguna Jasa; dan

Notaris wajib melakukan verifikasi terhadap informasi dan dokumen. Dalam hal ini Notaris dapat meminta keterangan kepada Pengguna Jasa untuk mengetahui kebenaran formil dokumen dan apabila terdapat keraguan atas kebenaran formil dokumen, Notaris dapat meminta dokumen pendukung lainnya dari pihak yang berwenang.

Verifikasi terhadap informasi dan dokumen dilaksanakan sebelum melakukan hubungan usaha dengan Pengguna Jasa. Notaris dapat melakukan hubungan usaha atau transaksi sebelum proses verifikasi selesai, apabila notaris telah menerapkan prosedur manajemen risiko. Bila notaris melakukan hubungan usaha sebelum proses verifikasi selesai maka proses verifikasi wajib diselesaikan sesegera mungkin, setelah terjadinya hubungan usaha pengguna jasa dengan notaris. Hubungan usaha dilakukan dengan memperhatikan risiko pencucian uang dan pendanaan terorisme dapat dikelola secara efektif dan proses pertemuan langsung ini tidak mengganggu kegiatan usaha secara normal.

c. Pemantauan Transaksi Pengguna Jasa.

Notaris melakukan pemantauan kewajaran Transaksi Pengguna Jasa. Dalam hal pencatatan transaksi dan sistem informasi seorang Notaris bertanggung jawab terhadap adanya pencatatan transaksi dan sistem informasi mengenai identifikasi, pemantauan, dan penyediaan laporan mengenai transaksi yang dilakukan oleh Pengguna Jasa. Pencatatan transaksi dan sistem informasi dapat dilakukan secara non elektronik maupun elektronik yang disesuaikan dengan kompleksitas dan karakteristik Notaris. Sistem informasi yang dimiliki memungkinkan notaris untuk menelusuri setiap transaksi apabila diperlukan, baik untuk keperluan internal dan/atau kementerian yang menyelenggarakan urusan pemerintahan di bidang hukum, maupun dalam kaitannya dengan penegakan hukum. 
Dengan menggunakan prinsip mengenal pengguna jasa ini dapat dilakukan identifikasi terhadap orang pribadi maupun terhadap perusahaan jasa penyalur tenaga kerja Indonesia baik untuk tujuan domestik maupun yang melintasi batas teritorial Indonesia, sehingga akan mempersulit pengguna jasa untuk melakukan manipulasi terhadap identitas pribadi/perusahaan, demikian juga terhadap transaksi keuangannya.

Menurut Yunus Hussein, prinsip mengenal pengguna jasa, tidak ada salahnya bagi Notaris apabila lebih berhati-hati dalam melakukan transaksi dengan penghadapnya dalam upaya melakukan pencegahan dalam TPPU berdasarkan UUPPTPPU, dan untuk itu ada beberapa hal yang perlu dilakukan oleh Notaris, yaitu:

a. Kegiatan mengenali pengguna jasa yaitu sesuai Undang-Undang No.8 Tahun 2010 tentang Pencegahan dan Pemberantasan Tindak Pidana Pencucian Uang (TPPU) terdapat beberapa pengaturan mengenai kewajiban Pengguna jasa seperti memberikan identitas dan informasi yang benar, sumber dana, dan tujuan transasksi pihak lain tersebut.

b. Pengelolaan resiko yaitu Penerapan Prinsip Mengenali Pengguna Jasa (PMPJ) atau penerapan Program Prinsip Mengenal Nasabah dan Anti Pencucian Uang (APU PPT), merupakan bagian penting bagi manajemen risiko yang baik, terutama dalam pengelolaan risiko reputasi, risiko operasi, risiko hukum dan risiko konsentrasi, yang satu dengan lainnya saling berhubungan. Dalam hal pengenalan tingkat resiko, hendaknya perlu dilakukan pengelompokkan dan analisis terhadap identitas penghadap, profil penghadap, jumlah transaksi, kegiatan usaha penghadap dan informasi lainnya yang dapat digunakan untuk mengukur resiko penghadap.

c. Memenuhi prinsip Good Corporate Governance (CGC) yaitu transparasi/keterbukaan dalam mengemukakan informasi, akuntabilitas yaitukejelasan fungsi dan pelaksanaan pertanggungjawaban, pertanggungjawaban yaitu kesesuaian pengelolaan dengan peraturan perundang-undangan yang berlaku dan prinsip pengelolaan yang sehat

d. Independensi (Independency) yaitu pengelolaan secara profesional tanpa pengaruh/tekanan dari pihak manapun; dan kewajaran (fairness) yaitu 
keadilan dan kesetaraan dalam memenuhi hak-hak stakeholders yang timbul berdasarkan perjanjian dan peraturan perundang-undangan yang berlaku.

\section{Perlindungan hukum terhadap Notaris sebagai Pelapor indikasi TKM}

Selain mengatur mengenai kewajiban-kewajiban bagi pihak pelapor dalam melaporkan TKM, beberapa ketentuan dalam UU PPTPPU juga memberikan perlindungan hukum kepada pihak pelapor yang melaporkan adanya TKM kepada PPATK. Tidak dapat dipungkiri bahwa salah satu kunci keberhasilan negara dalam mencegah dan memberantas TPPU adalah keikutsertaan masyarakat terutama pihak pelapor dalam membantu aparat penegak hukum. Peran penting pelapor dalam pencegahan dan pemberantasan TPPU seharusnya sejalan dengan perlindungan-perlindungan hukum yang diberikan oleh negara. Secara tidak langsung laporan yang diberikan oleh pelapor kepada aparat penegak hukum adalah perbuatan yang mengandung resiko yang besar terhadap keselamatan dirinya, keluarganya serta harta benda miliknya.

Perlindungan hukum bagi pihak pelapor atas TKM terkait TPPU dibagi menjadi dua yaitu sebelum berlakunya UU PPTPPU dan sesudah berlakunya UU PPTPPU. Sebelum berlakunya UU PPTPPU perlindungan atas hak-hak pelapor diatur dalam Undang-Undang Nomor 13 Tahun 2006 tentang Perlindungan Saksi dan Korban (UU PSK). Secara khusus perlindungan bagi Pelapor dan Saksi TPPU telah diatur dalam Peraturan Pemerintah Nomor 57 Tahun 2003 tentang Tata Cara Perlindungan Khusus Bagi Pelapor dan Saksi Tindak Pidana Pencucian Uang. Ketentuan teknis dalam pemberian perlindungan bagi pelapor dan saksi dalam tindak pidana pencucian uang diatur melalui Peraturan Kepala Kepolisian Negara Republik Indonesia (Kapolri) Nomor 17 Tahun 2005 tentang Tata Cara Pemberian Perlindungan Khusus terhadap Pelapor dan Saksi dalam Tindak Pidana Pencucian Uang.

Ketentuan mengenai perlindungan khusus ditegaskan dalam Pasal 2 Peraturan Pemerintah Nomor 57 Tahun 2003 menegaskan bahwa setiap pelapor dan Saksi dalam perkara TPPU wajib diberikan perlindungan khusus baik sebelum, selama maupun sesudah proses pemeriksaan perkara bentuk perlindungan khusus yang dimaksud adalah perlindungan atas keamanan pribadi dari ancaman fisik dan mental, perlindungan terhadap harta, perlindungan berupa 
kerahasiaan dan penyamaran identitas, dan memberikan keterangan tanpa bertatap muka (konfrontasi) dengan tersangka atau terdakwa pada setiap tingkatan pemeriksaan perkara

Pengaturan mengenai perlindungan bagi Pelapor dan Saksi dalam UndangUndang Nomor 8 Tahun 2010 tentang Pencegahan dan Pemberantasan Tindak Pidana Pencucian Uang terdapat di dalam Bab IX yaitu terdapat pada Pasal 83-87. UU PPTPPU menegaskan pengaturan perlindungan-perlindungan hukum yang diberikan kepada pihak pelapor atas jasanya yang melaporkan TKM terkait TPPU Bentuk perlindugan hukum pertama yang diberikan UU PPTPPU adalah adanya kewajiban hukum bagi PPATK, penyidik, penuntut umum serta hakim untuk merahasiakan identitas dari pelapor TPPU.

Beberapa ketentuan dalam UU PPTPPU menegaskan bahwa pihak pelapor atas kewajibannya melaporkan transaksi keuangan mencurigakan terkait tindak pidana pencucian uang tidak dapat dituntut baik secara perdata maupun pidana. Hal ini diatur dalam Pasal 5 ayat (2), Pasal 29, dan Pasal 87 ayat (1) UU PPTPPU. Dalam hal ini Notaris yang dikategorikan sebagai pihak pelapor atas transaksi keuangan mencurigakan tidak dapat dituntut oleh siapapun baik perdata maupun pidana karena telah melaporkan transaksi keuangan mencurigakan kepada PPATK.

Dalam ketentuan Pasal 4 UUJN memang terdapat ketentuan imperative bahwa diwajibkannya notaris untuk bersumpah/janji merahasiakan isi akta yang dibuatnya kecuali undang-undang menentukan lain sebagaimana diatur dalam Pasal 16 ayat (1 huruf f). Dengan demikian, batasannya hanya Undang-Undang yang dapat memerintahkan notaris untuk membuka rahasia isi akta dan keterangan/pernyataan yang diketahui oleh notaris yang berkaitan dengan pembuatan akta yang dimaksud. ${ }^{10}$

Beberapa upaya mengatasi kendala pencegahan tindak pidana pencucian uang terkait confidentiality of client sebagai kewajiban pelaporan bagi notaris dilakukan, tetap saja menimbulkan dilema bagi notaris dalam menjalankan profesi/jabatannya terikat dengan kerahasiaan yang diatur dalam peraturan perundang-undangan tersendiri.

${ }^{10}$ Habib Adjie, Meneropong Khazanah Notaris dan PPAT (Kumpulan Tulisan tentang Notaris dan PPAT), Cetakan I, (Bandung: PT.Citra Aditya Bakti, 2009), hlm.6. 
Meskipun terdapat rangkaian peraturan perundang-undangan yang menempatkan posisi berbeda bagi profesi atau jabatan, tentunya tidak semudah pelaksanaannya dalam praktik. Prinsip menghormati kerahasiaan jabatan maupun Akta secara sistemik akan menjadi terbuka dan transparan, kepentingan masyarakat yang membutuhkan layanan/jasa profesional harus berdiri di posisi bahwa semua informasi memiliki potensi terbuka. Persoalan berikutnya adalah kewajiban sebagai pelapor bagi profesi tentunya tidak bisa disamakan dengan pihak pelapor institusi lembaga jasa keuangan (perbankan, asuransi, pembiayaan) atau institusi lainnya. Karena profesi dijalankan sebagai pribadi dengan segala risiko yang menyertainya termasuk kriminalisasi, tentunya kepatuhan profesi menjalani kewajiban sebagai pelapor juga harus dilindungi dengan maksimal oleh aparat penegak hukum.

Menjadi tantangan tersendiri bagi masing-masing profesi untuk menentukan apakah suatu perbuatan atau tindakan itu memenuhi kualifikasi sebagai transaksi yang mencurigakan atau tidak. Hal ini dikarenakan masing-masing profesi belum tentu mengetahui dan menguasai, bahkan bisa jadi tidak mengerti bagaimana mendeteksi dan menilai suatu kejadian atau perbuatan termasuk dalam kategori TKM.

Korporasi kerap kali digunakan untuk menyembunyikan dan menyamarkan identitas pelaku dan hasil tindak pidana. Penguatan peraturan dan penerapan transparansi informasi beneficial ownership dari korporasi di Indonesia saat ini dinilai sudah sangat mendesak. Sebab, tingkat ancaman TPPU yang dilakukan korporasi saat ini lebih tinggi dibandingkan perorangan. Terbitnya Peraturan Presiden Nomor 13 Tahun 2018 tentang Penerapan Prinsip Mengenali Pemilik Manfaat dari Korporasi merupakan langkah progresi karena akan mendorong transparansi informasi dan pada hakikatnya memuat pengaturan dan mekanisme untuk mengenali pemilik manfaat dari suatu korporasi

Meskipun terdapat rangkaian peraturan perundang-undangan yang menempatkan posisi berbeda bagi profesi atau jabatan, tentunya tidak semudah pelaksanaannya dalam praktik. Prinsip menghormati kerahasiaan jabatan maupun Akta secara sistemik akan menjadi terbuka dan transparan, kepentingan masyarakat yang membutuhkan layanan/jasa profesional harus berdiri di posisi 
16 ADIL: Jurnal Hukum Vol. 9 No.2

bahwa semua informasi memiliki potensi terbuka. Persoalan berikutnya adalah kewajiban sebagai Pelapor bagi profesi tentunya tidak bisa disamakan dengan pihak Pelapor institusi lembaga jasa keuangan (perbankan, asuransi, pembiayaan) atau institusi lainnya. Karena profesi dijalankan sebagai pribadi dengan segala risiko yang menyertainya termasuk kriminalisasi, tentunya kepatuhan profesi menjalani kewajiban sebagai Pelapor juga harus dilindungi dengan maksimal oleh aparat penegak hukum. 


\section{DAFTAR PUSTAKA}

\section{Buku}

Adjie, Habib. Meneropong Khazanah Notaris dan PPAT (Kumpulan Tulisan tentang Notaris dan PPAT), Cetakan I, Bandung: PT.Citra Aditya Bakti, 2009. . Menjalin Pemikiran-Pendapat Tentang Kenotariatan (Kumpulan Tulisan), Bandung: PT.Citra Aditya Bakti, 2013.

Lumban Tobing, G.H.S. Peraturan Jabatan Notaris (Notaris Reglement), (Jakarta: Erlangga, 1999.

Notodisoerjo, Raden Soegondo. Hukum Notariat di Indonesia suatu Penjelasan, cetakan kedua. Jakarta: PT. RajaGrafindo Persada, 1993.

Soegondo Notodisoerjo, Raden. Hukum Notariat di Indonesia suatu Penjelasan, cetakan kedua, (Jakarta: PT. Raja Grafindo Persada, 1993.

Tedjosaputro, Liliana. Etika Profesi Notaris (Dalam Penegakan Hukum Pidana), Yogyakarta: Bigraf Publishing, 1995.

CV. Agung, 1991. . Malpraktek Notaris dan Hukum Pidana, (Semarang:

Thong Kie,Tan. Studi Notariat, Serba-serbi Praktek Notaris, Buku I (Jakarta :PT Ichtiar Baru Van Hoeve, 2000).

Untung, Budi. Hukum Koperasi dan Peran Notaris Indonesia. Yogyakarta: Andi, 2005.

\section{Peraturan Perundang-undangan}

Indonesia, Undang-Undang Republik Indonesia tentang Perubahan Atas Undang-Undang Nomor 30 Tahun 2004 tentang Jabatan Notaris, UU No. 2 LN Tahun 2014 No. 3, TLN No. 5491.

, Undang-Undang Republik Indonesia tentang Pencegahan dan Pemberantasan Tindak Pidana Pencucian Uang, UU No. 8 LN Tahun 2010 No. 122, TLN No. 5164.

, Peraturan Pemerintah Republik Indonesia tentang Pihak Pelapor Dalam Pencegahan dan Pemberantasan Tindak Pidana Pencucian Uang, PP No. 43 Tahun 2015.

, Peraturan Menteri Hukum dan HAM tentang Penerapan Prinsip Mengenali Pengguna Jasa, Permenkumham Nomor 9 Tahun 2017.

Peraturan Presiden (Perpres) Nomor 13 Tahun 2018 Tentang Penerapan Prinsip Mengenali Pemilik Manfaat Dari Korporasi Dalam Rangka 
18 ADIL: Jurnal Hukum Vol. 9 No.2

Pencegahan dan Pemberantasan Tindak Pidana Pencucian Uang dan Tindak Pidana Pendanaan Terorisme. 